\title{
Neuropathological findings in entorhinal cortex of subjects aged 50 years or older and their correlation with dementia in a sample from Southern Brazil
}

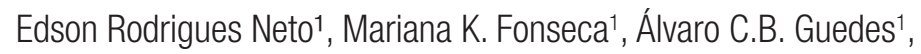 \\ Francine H. Oliveira², Arlete Hilbig ${ }^{3}$, Liana Lisboa Fernandez ${ }^{4}$
}

\begin{abstract}
Introduction: The aims of this study were to survey neurodegenerative changes detected by abnormal protein deposits in the Entorhinal Cortex (EC) of subjects aged 50 years or older and to correlate these findings with suspected dementia, as detected by the IQCODE (Informant Questionnaire on Cognitive Decline in the Elderly). Methods: Fourteen brains were submitted to the immunohistochemistry technique for different proteins (beta-amyloid, tau, $\alpha$-synuclein and phospho-TDP-43) and data obtained compared with IQCODE scores. Results: Fifty-seven percent of the individuals exhibited IQCODE results compatible with dementia, being classified into the demented group (DG): $87.5 \%$ of patients had neuropathological findings corresponding to Alzheimer's-like brain pathology (ALBP). Of the patients in the nondemented group (NDG), 16.7\% met neuropathological criteria for ALBP. All individuals in the DG showed deposits of more than one kind of protein in the EC. The most common association was hyperphosphorylated tau and beta-amyloid protein (87.5\%). Discussion: Most individuals with dementia had neuropathological findings of ALBP, as did one individual with no signs of dementia, characterizing a preclinical stage. The results of this study suggest that deposits of a single type of anomalous protein are normal findings in an aging brain, while more than one kind of protein or the combined presence of anomalous protein deposits indicate the presence of dementia.
\end{abstract}

Key words: dementia, Alzheimer, entorhinal cortex, immunohistochemistry, anomalous protein deposits, IQCODE.

ACHADOS NEUROPATOLÓGICOS NO CÓRTEX ENTORRINAL DE ENCÉFALOS DE INDIVÍDUOS ACIMA DE 50 ANOS E SUA
CORRELAÇÃO COM DEMÊNCIA NUMA AMOSTRA DO SUL DO BRASIL RESUMO. Introdução: Este trabalho visa avaliar alterações neurodegenerativas detectadas por depósitos proteicos anormais em Córtex Entorrinal (CE) de indivíduos acima de 50 anos e correlacionar os achados com suspeição de demência detectada por meio do IQCODE (Informant Questionnaire on Cognitive Decline in the Elderly). Métodos: Catorze encéfalos foram submetidos à técnica imuno-histoquímica para diferentes proteínas (beta-amiloide, tau, alfasinucleína e fosfo-TDP-43) e esses dados foram comparados com os valores obtidos pelo IQCODE. Resultados: $57 \%$ dos indivíduos mostraram resultados de IQCODE compatíveis com demência, sendo classificados no grupo com demência (GD): 87,5\% desses pacientes tinham achados neuropatológicos correspondentes a patologia cerebral Alzheimersímile (ALBP). Entre os pacientes do grupo sem demência (GSD), 16,7\% apresentaram critérios neuropatológicos para ALBP. Todos os indivíduos do GD tinham depósitos de mais de um tipo de proteína no CE. A associação proteica mais comum foi tau hiperfosforilada e proteína beta-amiloide $(87,5 \%)$. Discussão: A maioria dos indivíduos com demência apresentaram achados neuropatológicos de ALBP e um indivíduo, que não tinha evidências de demência, apresentou achados compatíveis com ALBP, caracterizando um estágio pré-clínico. Este trabalho sugere que depósitos de um único tipo de proteína anômala são achados normais do cérebro em envelhecimento, enquanto mais de um tipo de proteínas ou a presença combinada de depósitos proteicos anômalos indica manifestações de demência.

Palavras-chave: demência, Alzheimer, córtex entorrinal, imuno-histoquímica, depósitos proteicos anômalos, IQCODE.

This study was conducted at the Federal University of Health Sciences of Porto Alegre (UFCSPA), Porto Alegre RS, Brazil.

${ }^{1}$ Medical Student at the Federal University of Health Sciences of Porto Alegre (UFCSPA). Scientific initiation scholars of the Foundation for Research of Rio Grande do Sul. ${ }^{2}$ Pathologist. Specialist in Neuropathology at the Institute of Neuropathology of the University Hospital of Zurich. MSc in Pathology at the Federal University of Health Sciences of Porto Alegre, Porto Alegre RS, Brazil. ${ }^{3}$ Neurologist. PhD in Internal Medicine at the Federal University of Rio Grande do Sul, Porto Alegre RS, Brazil. Associate Professor at the Federal University of Health Sciences of Porto Alegre, Porto Alegre RS, Brazil. ${ }^{4}$ Neurologist. PhD in Cellular and Molecular Biology at the Pontifical Catholic University of Rio Grande do Sul, Porto Alegre RS, Brazil and the University of Barcelona, and Adjunct Professor at the Federal University of Health Sciences of Porto Alegre, Porto Alegre RS, Brazil.

Edson Rodrigues Neto. UFCSPA - R. Sarmento Leite, 245 / Sala 006 - 90050-170 Porto Alegre RS - Brazil. E-mail: erodriguesneto@gmail.com

Disclosure: The authors report no conflicts of interest.

Received October 13, 2016. Accepted in final form February 09, 2016. 


\section{INTRODUCTION}

B razil stands out as a country with high growth rates Bof the elderly population, with ageing projections of about 32 million people aged over 65 years by 2025. An older population emerges as a problem for studying and planning public policies, due to the inevitable growth in demand for healthcare. ${ }^{1,2}$ Hence, an increase incidence of neurodegenerative diseases can be expected. Neurodegenerative diseases affect specific regions of the nervous system with insidious onset and a relentless progressive course. ${ }^{3}$ They form deposits of proteins that change their conformation, becoming anomalous forms. ${ }^{4}$

This is the case in Alzheimer's disease (AD), Frontotemporal Dementia (FTD), Amyotrophic Lateral Sclerosis (ALS), Parkinson's disease (PD), Dementia with Lewy Bodies (DLB), Multiple System Atrophy (MSA), among others. $^{4}$

$\mathrm{AD}$ is the most common neurodegenerative disease and can lead to dementia, significantly compromising memory and other cognitive functions, with sufficient intensity to produce functional loss. Impairments in the execution of daily and social activities, such as recognizing people and places in habitual surroundings are common symptoms. ${ }^{5-8}$ The definitive diagnosis of $\mathrm{AD}$ depends strictly on the histopathological examination of the post-mortem brain. It is conducted by identifying the selective loss of neurons in specific areas, as well as through the detection of senile plaques (SP) and neurofibrillary tangles (NFT), which involves the presence of proteins such as $\beta$-amyloid (A $\beta)$ and hyperphosphorylated TAU, respectively. ${ }^{5,9}$

$\mathrm{PD}$, the second-most-common neurodegenerative disorder, is characterized as a multisystem disease, presenting with motor symptoms: tremor, bradykinesia, changes in balance and muscle tone; and non-motor symptoms: olfactory deterioration, sleep disorders, urinary, gastrointestinal and cardiovascular abnormalities; pain and depression. ${ }^{10}$ Its pathological diagnosis includes selective neuronal loss in the pars compacta of the substantia nigra, as well as the presence of Lewy bodies rich in $\alpha$-synuclein. ${ }^{11}$ Deposits of this protein can also be found in DLB and MSA. ${ }^{12}$

Amongst the different varieties of FTD, three main syndromes may be recognized: behavioral variant frontotemporal dementia (bv-FTD), presenting with personality and behavioral changes; semantic dementia (SD) with fluent language alteration; or progressive nonfluent aphasia (PNFA), characterized by nonfluent language alteration. ${ }^{13-15}$ Despite the impairment-based classification, there is also a clinical, pathological and genetic overlap. For instance, SD cases may develop features of
bv-FTD, and there is also an overlap between FTD and other neurodegenerative diseases such as progressive supranuclear palsy (PSP), and corticobasal degeneration (CBD) and ALS. ${ }^{16}$ TAR DNA-binding protein 43 (TDP43), whose gene is located on chromosome 1 , has been linked to the pathogenesis of FTD and ALS. This intranuclear protein is involved in different cellular processes such as gene transcription, alternative splicing, mRNA stability, microRNA biogenesis, cell division and apoptosis. If modified, the molecule changes its pattern of distribution and function throughout the CNS structures. ${ }^{17}$

The Entorhinal Cortex (EC) is the anterior portion of parahippocampal gyrus of the temporal lobe. It is an important connection point between cerebral cortex areas and the hippocampus, converging visual, auditory and somatosensorial information. Conversely, efferent fibers of the hippocampus, originating in the subiculum and CA1, return to the EC, participating in the Papez circuit, which relates to emotional reactions. Several neuropathological changes in the $\mathrm{EC}$, such as those occurring in the $\mathrm{AD}$, isolate or disconnect the hippocampus from the rest of cerebral cortex, resulting in severe memory loss. ${ }^{18}$

The aim of this study was to survey neurodegenerative changes detected by abnormal protein deposits in the EC of subjects aged 50 years or older, using Immunohistochemistry reactions (IHC) and to correlate findings with suspected dementia.

\section{METHODS}

A descriptive study was conducted in which brain samples were collected at post-mortem autopsies by convenience after informed consent of first-degree relatives. Twelve brains were collected from subjects aged 50 years or older who underwent death verification at the Forensics Department (FD) of Porto Alegre, Southern Brazil. Individuals with violent deaths, subjects whose relatives did not give consent, and those who had acute neurological events (i.e., stroke) as cause of death were excluded. Two brains were extracted from patients followed-up at the Department of Neurology of ISCMPA -- the hospital of the University in Porto Alegre. Donors' clinical information were obtained after death by interviewing the next-of-kin using a questionnaire to evaluate cognitive decline - the Informant Questionnaire on Cognitive Decline in the Elderly (IQCODE) - which has been shown as a reliable screening test for cognitive decline based on neuropathological diagnosis as the criterion..$^{19}$ For the IQCODE, a cut-off point score for dementia of $\geq 3.27$ was adopted, as suggested by Sanchez et al. ${ }^{20}$ All brains were formalin-fixed for 
4 weeks and cut using standard protocols. Samples including the EC were embedded in paraffin and 5 - $\mu$ m-thick serial sections cut using a microtome for subsequent use in IHC reactions. Sections were placed on glass slides and deparaffinized in xylene, hydrated using a graded series of ethanol, and immersed in $3 \%$ hydrogen peroxide in $100 \%$ methanol for $15 \mathrm{~min}$ to inhibit endogenous peroxidase activity. To activate the antigens, sections were boiled in $10 \mathrm{mM}$ citrate buffer, $\mathrm{pH}$ 6.0, or formic acid. After rinsing in phosphatebuffered saline (PBS), the sections were incubated with normal horse serum for $2 \mathrm{~h}$ and then incubated overnight at $4^{\circ} \mathrm{C}$ in humid chambers with the primary antibody. The following primary antibodies were used: (1) anti-A $\beta$ (monoclonal mouse, anti-human beta-amyloid, Dakocytomation, Denmark), dilution 1:25, pretreated for 3 minutes with formic acid; (2) anti-tau (monoclonal mouse anti-human PHF-tau, at-8, Innogenetics), dilution 1:500, pretreated with citrate for 10 minutes; (3) anti- $\alpha$-synuclein (monoclonal mouse anti $\alpha$-synuclein, Novocastra), dilution 1:200, pretreated with formic acid for 4 minutes and citrate for 20 minutes; and (4) anti-phospho-TDP-43 (Cosmo Bio Co, Tip-PDT-P05), dilution 1:2500, pretreated with citrate for 20 minutes. After overnight incubation in antibodies, the slides were washed three times in PBS and incubated in DAKO secondary polymer for 40 minutes, Streptavidin HRO,
DAKO for 30 minutes, and finally treated for 3 min with $0.01 \% \mathrm{H}_{2} \mathrm{O}_{2}$ and $0.05 \%$ diaminobenzidine tetrahydrochloride (DAB, Sigma). All slides were counterstained with hematoxylin for 10 seconds, and then evaluated under light microscope for protein deposits by three independent observers. The protein deposit reactions and patterns were semi-quantified using a number scale: 1 (absent), $2(+), 3(++)$ and $4(+++)$ (Figure 1). Clinical data was correlated with pathological findings using Fisher's test (significant results $\mathrm{p}<0.05$ ) or expressed as percentages. The University (UFCSPA) Ethics Committees approved the study.

\section{RESULTS}

Analyzing the sample of 14 individuals, we found that 57\% (8 individuals) exhibited IQCODE results $>3.27$, compatible with dementia (DG). The mean IQCODE value in the non-demented group (NDG) (6 individuals) was 2.745, while the mean of the DG was 3.72. The DG had a mean age of 72.87 years while the NDG group, 71.16 years. Fifty percent of individuals in each sample (7 individuals) were female (Figure 2).

In the DG, $87.5 \%$ (7 individuals) had neuropathological findings that corresponded to ALBP (Alzheimer'slike brain pathology): $14.28 \%$ at Braak stages I and II, with CERAD A, $42.8 \%$ at stages III and IV, with CERAD $\mathrm{A}, \mathrm{B}$ or $\mathrm{C}$, and $42.8 \%$ at stages $\mathrm{V}$ and $\mathrm{VI}$, with CERAD C. ${ }^{21}$
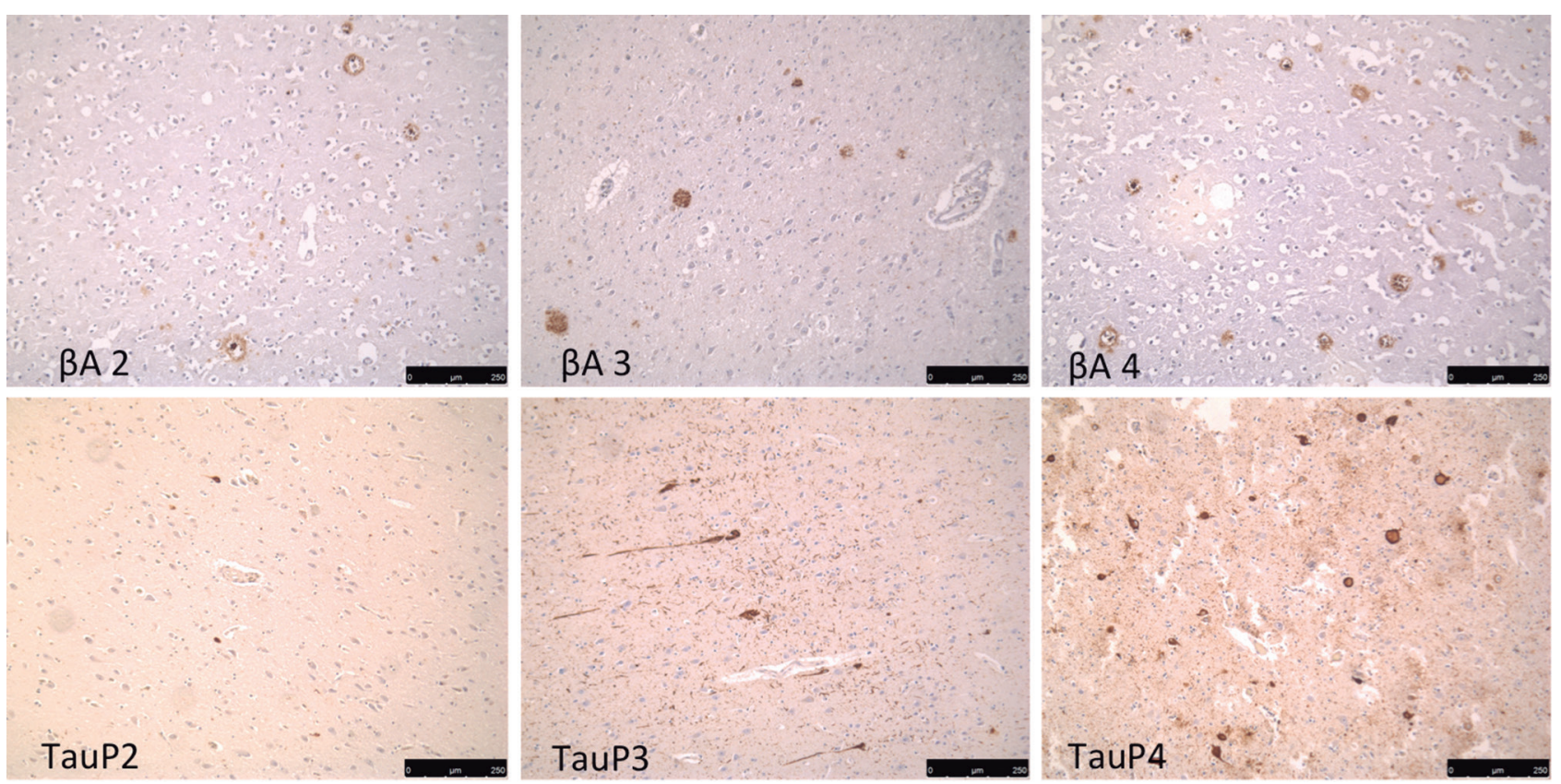

Figure 1. Semi-quantified deposit reactions: $\beta A 2$ : $\beta$-amyloid +/sparse neuritic plaques; $\beta$ A3: $\beta$-amyloid ++/moderate neuritic plaques; $\beta$ A4: $\beta$-amyloid +++/frequent neuritic plaques. TauP2: AT8 +/sparse neurofibrillary tangles; TauP3: AT8 ++/moderate neurofibrillary tangles; TauP4: AT8 +++/frequent neurofibrillary tangles. 
To classify Braak stages, the distribution of NFT was determined using AT8 IHC reaction in all brain regions. For CERAD classification, the authors studied neurite plaque density (sparse, moderate or frequent) in the middle frontal gyrus, superior and middle temporal gyri and inferior parietal lobule (data not published). ${ }^{22}$ Twelve and a half percent of subjects (1 individual) from the DG presented $\alpha$-synucleinopathy, which was an MSA case (diagnosis based on neuropathological findings and clinical manifestations from the medical specialist records kept when patient was in hospital). In addition, 25\% (2 individuals) of subjects had phosphoTDP-43-proteinopathy: one case compatible with FTD/ ALS (diagnosis based on neuropathological findings and clinical manifestations from the medical specialist records kept when patient was in hospital) associated with ALBP Braak stage I-II, and another case of ALBP Braak stages V-VI. Twenty-five percent (2 individuals) of DG cases showed amyloid angiopathy and $12.5 \%$ (1 individual) lacunar stroke.

In the NDG, 16.7\% ( 1 individual) met neuropathological criteria for ALBP Braak stages III-IV. Isolated tauopathy was seen in $66.7 \%$ (4 individuals) of the group and isolated $\beta$-amyloidopathy in $16.7 \%$ ( 1 individual). The cause of death was also described (Table 1 ).

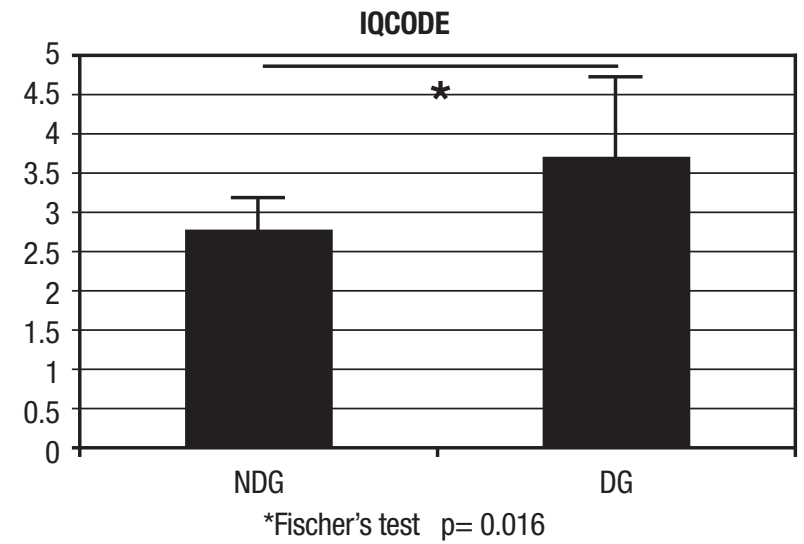

IQCODE: Informant Questionnaire on Cognitive Decline in the Elderly. NDG: Non-demented group. DG: Demented group.

Figure 2. Profile of sample: average IQCODE in groups.

On the semi-quantitative assessment of protein deposits in the EC detected by IHC, only one individual from the whole sample (7.14\%) had no protein deposits where this case belonged to the NDG. However, regarding individuals that had deposits in the EC, all individuals from the DG showed deposits of at least two of the proteins studied (Figure 3). The most common association was the presence of both hyperphosphorylated tau
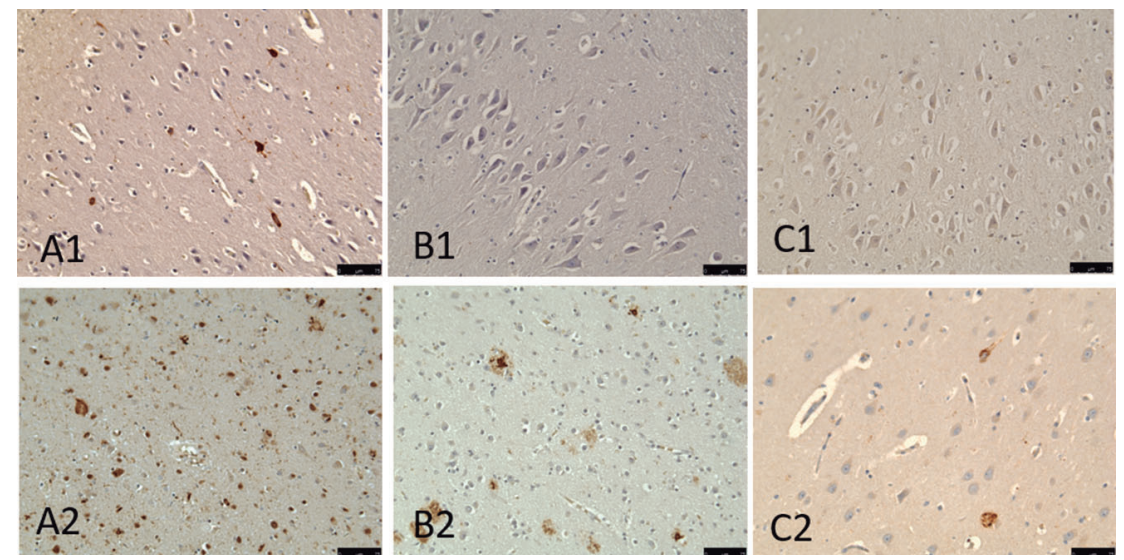

Entorhinal cortex

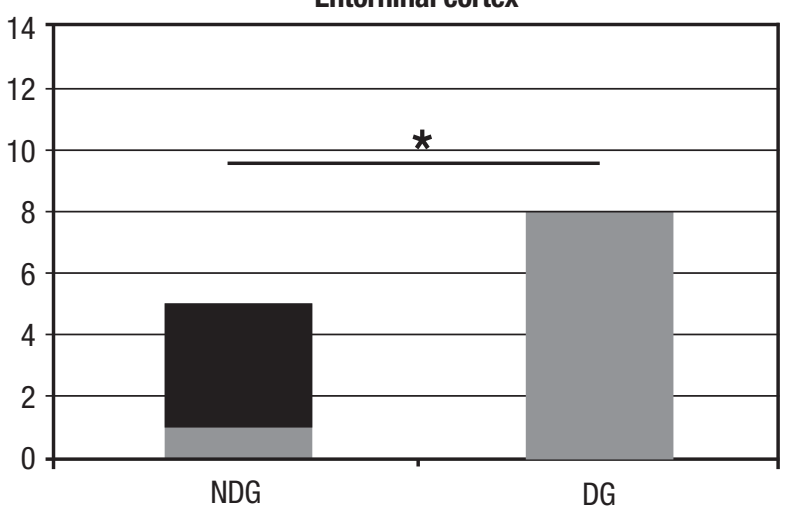

$D G$
*Fischer's test $p=0.007$

Unique protein deposits

More than one kind of protein deposit

NDG: Non-demented group. DG: Demented group.

Figure 3. Immunohistochemistry technique showing protein deposits (A: TAU; B: $\beta$-amyloid; C: PhosphoTDP-43) in Entorhinal cortex of non-demented (NDG: 1) and demented (DG: 2) groups. 
Table 1. Anatomopathological diagnosis of 14 brains based on the presence and distribution of IHC reaction for $\beta$-amyloid, $\alpha$-synuclein, AT8 (anti-tau) and phospho-TDP-43 in EC.

\begin{tabular}{|c|c|c|c|c|c|}
\hline \multicolumn{6}{|c|}{ Non-Demented Group (NDG) } \\
\hline Cases & Sex & Age (years) & IQCODE* & Anatomopathological diagnosis & Cause of death \\
\hline 020611-1 & $\mathrm{F}$ & 91 & 1.32 & Tauopathy & Pneumonia \\
\hline 020611-2 & M & 79 & 3.15 & Tauopathy & Cardiac Tamponade \\
\hline 030811 & M & 56 & 3.00 & Tauopathy & Undetermined \\
\hline 241111 & $\mathrm{~F}$ & 89 & 3.00 & $\begin{array}{l}\text { ALBP / Braak: III-IV ** CERAD B*** } \\
\text { (Tauopathy }+\beta \text {-amyloidopathy) }\end{array}$ & Multiorgan failure \\
\hline 140312 & M & 50 & 3.00 & $\beta$-amyloidopathy & Undetermined \\
\hline 210612 & $\mathrm{~F}$ & 62 & 3.00 & Tauopathy & Undetermined \\
\hline Average $/ \mathrm{n}(\%)^{\star \star \star \star \star}$ & $\mathrm{F}: 50 \%$ & $\begin{array}{c}71.16 \\
\text { (SD: } 17.52)\end{array}$ & $\begin{array}{c}2.74 \\
(\mathrm{SD}: 0.63)\end{array}$ & ALBP $16.7 \%$ & \\
\hline \multicolumn{6}{|c|}{ Demented Group (DG) } \\
\hline Cases & Sex & Age (years) & IQCODE* & Anatomopathological diagnosis & Cause of death \\
\hline 120611 & $\mathrm{~F}$ & 59 & 4.52 & MSA $^{* \star \star \star}$ ( $\alpha$-synucleinopathy) and Tauopathy & Septic Shock \\
\hline 050811 & $\mathrm{~F}$ & 93 & 3.33 & $\begin{array}{l}\text { ALBP / Braak: III-IV ** CERAD A }{ }^{\star * *} \\
\text { (Tauopathy + } \beta \text {-amyloidopathy) }\end{array}$ & Myocardial Infarction \\
\hline 041111 & $\mathrm{~F}$ & 68 & 3.27 & $\begin{array}{l}\text { ALBP / Braak: III-IV ** CERAD B }{ }^{\star * *} \\
\text { (Tauopathy + amyloidopathy- } \beta \text { ) }\end{array}$ & Undetermined \\
\hline 160312 & M & 54 & 3.86 & $\begin{array}{l}\text { FTD/ALS }{ }^{\star \star \star} \text { (TDP-43proteinopathy) } \\
\text { ALBP / Braak: I-II ** CERAD A }{ }^{\star \star \star} \\
\text { (Tauopathy + } \beta \text {-amyloidopathy) }\end{array}$ & Pneumonia \\
\hline 170312 & M & 95 & $4 . .77$ & $\begin{array}{l}\text { ALBP / Braak: V-VI ** CERAD C } C^{* * *} \\
\text { (Tauopathy }+\beta \text {-amyloidopathy) } \\
\text { TDP-43 proteinopathy }\end{array}$ & Acute pulmonary edema \\
\hline 100412 & M & 62 & 3.38 & $\begin{array}{l}\text { ALBP / Braak: III-IV** CERAD C } \\
\text { (Tauopathy }+\beta \text {-amyloidopathy) } \\
\text { Amyloid angiopathy }\end{array}$ & Liver cirrhosis \\
\hline 170512 & $\mathrm{~F}$ & 81 & 3.36 & $\begin{array}{l}\text { ALBP / Braak: V-VI ** CERAD C }{ }^{* * *} \\
\text { (Tauopathy }+\beta \text {-amyloidopathy) }\end{array}$ & Undetermined \\
\hline 220712 & M & 71 & 3.28 & $\begin{array}{l}\text { ALBP / Braak: V-VI ** CERAD C }{ }^{* * *} \\
\text { (Tauopathy }+\beta \text {-amyloidopathy) } \\
\text { Amyloid angiopathy } \\
\text { Parieto-occipital lacunar stroke }\end{array}$ & Cardiac tamponade \\
\hline Average/n(\%) & $\mathrm{F}: 50 \%$ & $\begin{array}{c}72.87 \\
\text { (SD: } 15.37)\end{array}$ & $\begin{array}{c}3.72 \\
(\mathrm{SD}: 0.60)\end{array}$ & ALBP: $87.5 \%$ & \\
\hline
\end{tabular}

ALBP: Alzheimer's-like brain pathology (Tauopathy + $\beta$-amyloidopathy). SD: Standard deviation. *IQCODE: Informant Questionnaire on Cognitive Decline in the Elderly; **Braak classification based on the presence of NFT detected by AT8 (anti-tau) IHC analysis of all brain regions (data not published); ${ }^{\star \star \star C E R A D ~ c l a s s i f i c a t i o n ~ b a s e d ~ o n ~ n e u r i t i c ~ p l a q u e ~ d e n s i t y ~ i n ~ m i d d l e ~ f r o n t a l ~ g y r u s, ~ s u p e r i o r ~ a n d ~}$ middle temporal gyri and inferior parietal lobule (data not published); ${ }^{\star \star \star \star}$ Diagnosis based on neuropathological findings and clinical manifestations from the medical specialist records kept when patients were in hospital; ${ }^{\star \star \star \star \star} n(\%)$ : frequency (percentage). 
Table 2. Positive IHC distribution for A $\beta$ ( $\beta$-amyloid), TAU (AT8), $\alpha$ SYN ( $\alpha$-synuclein) and Phospho-TDP-43 in EC (Entorhinal cortex) of non-demented (NDG) and demented (DG) groups.

\begin{tabular}{cccccc}
\hline Cases & IQCODE & A $\beta$ & TAU & $\alpha$ SYN & Phospho-TDP-43 \\
\hline $020611-1$ & 1.32 & $1(-)$ & $3(++)$ & $1(-)$ & $1(-)$ \\
\hline $020611-2$ & 3.15 & $1(-)$ & $2(+)$ & $1(-)$ & $1(-)$ \\
\hline 030811 & 3.00 & $1(-)$ & $1(-)$ & $1(-)$ & $1(-)$ \\
\hline 241111 & 3.00 & $2(+)$ & $2(+)$ & $1(-)$ & $1(-)$ \\
\hline 140312 & 3.00 & $2(+)$ & $1(-)$ & $1(-)$ & $1(-)$ \\
\hline 210612 & 3.00 & $1(-)$ & $2(+)$ & $1(-)$ & $1(-)$ \\
\hline Cases & IQCODE & A $\beta$ & TAU findings in EC of DG cases & $\alpha$ SYN & Phospho-TDP-43 \\
\hline 120611 & 4.52 & $1(-)$ & $2(+)$ & $2(+)$ & $1(-)$ \\
\hline 050811 & 3.33 & $2(+)$ & $4(+++)$ & $1(-)$ & $1(-)$ \\
\hline 041111 & 3.27 & $2(+)$ & $2(+)$ & $1(-)$ & $1(-)$ \\
\hline 160312 & 3.86 & $2(+)$ & $2(+)$ & $1(-)$ & $2(+)$ \\
\hline 170312 & 4.77 & $3(++)$ & $4(+++)$ & $1(-)$ & $2(+)$ \\
\hline 100412 & 3.38 & $2(+)$ & $2(+)$ & $1(-)$ & $1(-)$ \\
\hline 170512 & 3.36 & $2(+)$ & $3(++)$ & $1(-)$ & $1(-)$ \\
\hline 220712 & 3.28 & $3(++)$ & $3(++)$ & $1(-)$ & $1(-)$ \\
\hline
\end{tabular}

and $\mathrm{A} \beta$ ( $87.5 \%-7$ individuals) proteins, and $25 \%$ (2 individuals) of patients had three different reactive proteins (tau, $A \beta$ and phosphoTDP-43). In the NDG group, there were double deposits (hyperphosphorylated tau protein and $A \beta$ ) in only one individual (16.7\%) (Table 2). There was a statistically significant difference between the presence of unique deposits in the DG and NDG individuals on Fisher's test (significant results $\mathrm{p}<0.05$ - Figure 3).

\section{DISCUSSION}

The DG and NDG showed no statistical differences in relation to gender or age. The predominance of women in the DG is consistent with the fact that the most common dementia $(\mathrm{AD})$ has a higher prevalence in women. It was also assumed that the DG would have a higher mean age in comparison to the NDG, given the incidence of dementia increases with age. However, a larger number of samples can modify this data. The similarity between the two groups allows more reliable comparisons.

The fact that most individuals (57\%) had dementia, as determined by the IQCODE, suggests that family members of symptomatic individuals might be more sensitive in agreeing to organ and tissue donation. Close contact with debilitated people, the desire to help, and understanding the need for scientific research to relieve suffering and contribute to a cure in the future are factors positively influencing this decision. ${ }^{23-25}$

As expected, most individuals from the DG (87.5\%) presented neuropathological findings of ALBP. In an analysis of the prevalence of dementia in developing countries, $60 \%$ of cases were related to $\mathrm{AD}$ and approximately $30 \%$ of cases to vascular dementia (VD). However, none of these results have been validated by necropsy. ${ }^{26}$ While alive, the diagnosis of probable AD is made by exclusion of other forms of dementia and application of neuropsychological tests, specifically designed to evaluate cognitive ability. ${ }^{6}$ The prevalence of dementia in general, $\mathrm{AD}$ in particular, increases significantly with age. A Brazilian epidemiological study in the city of Catanduva (southeast Brazil) evaluated 1,656 people aged over 64 years and diagnosed dementia in 118 patients, corresponding to a prevalence of $7.1 \%$. Dementia was diagnosed in $38.9 \%$ individuals in the 
population over 85 years old. $\mathrm{AD}$ was the main cause of dementia, accounting for $55.1 \%$ of cases. Although the study has not been validated by necropsy, the prevalence of dementia increased with age and was higher in women, and was inversely correlated with education (3.5\% in people with over 8 years' education and $12.2 \%$ in illiterate individuals). ${ }^{6}$ However, a study carried out by the Brazilian Aging Brain Study Group (BABSG) of the University of São Paulo found that even a few years of formal education was associated with less cognitive impairment. ${ }^{27}$

Brunnstrom et al. (2009), studying the clinicalpathological concordance in the diagnosis of dementia, showed that $84 \%$ of patients with $\mathrm{AD}$ symptoms had the significant component of ALBP on the neuropathological examination. This association was slightly weaker for other types of dementia. The overall agreement, considering the mixed dementia findings, between clinical and pathological diagnosis was $63 \% .{ }^{28}$ Moreover, neuropathological studies can evaluate the association of several disorders, a common occurrence in the elderly. The most frequently found association was between ALBP and ischemic strokes, ${ }^{28,29}$ seen in one of our cases. There is also evidence that TDP-43 proteinopathy could be related with ALBP, especially in older adults with hippocampal sclerosis (HS). ${ }^{30-32}$ We found this association in two cases without HS, one with ALBP, Braak V-VI classification and the other in a case of FTD with ALS. Glia intracytoplasmic deposits of $\alpha$-synuclein are typical findings in MAS-Papp-Lantos bodies. ${ }^{33,34}$ We found this proteinopathy associated with NFT (tauopathy) in one case.

In the present study, only one individual, an 89-yearold women who was part of the NDG, had neuropathological findings corresponding to ALBP (Braak stage III-IV, CERAD B), characterizing a preclinical stage or resilience to protein toxicity. Studies show that, on evaluations of non-demented elderly, $45 \%$ exhibit neuropathological findings of ALBP. ${ }^{29,35}$

In our sample, only one individual in the NDG, a 56-year-old man, showed no deposits of the proteins studied in the EC. Other patients from the NDG presented at least some protein deposits, mostly single ones (A $\beta$ or hyperphosphorylated tau). Notably, all individuals in the DG showed more than one kind of protein deposit, being ALBP (A $\beta$ and hyperphosphorylated tau) in most cases (87.5\% - 7 individuals). AD corresponds to a disease spectrum ranging from asymptomatic lesions in cognitively normal elderly to elderly with classical dementia, in which a transition phase, Mild Cognitive Impairment (MCI), can be identified.${ }^{29}$ Clinical-patho- logical correlation studies have been crucial to establish the hypothesis on the pathophysiology of this continuum between normal aging and AD. SP primarily occur before the onset of cognitive symptoms, while NFT, neuronal loss and synaptic loss occur in parallel with cognitive decline. However, individuals with asymptomatic AD appear to be resilient to SP and NFT neurotoxicity. ${ }^{29,36}$

The study limitations included the small sample obtained, which was due to the logistical difficulty of collecting brains at the Forensics Department (FD) of Porto Alegre, and the absence of an established donation program that would allow a more extensive interview with family members. ${ }^{37}$ In addition, the fact that no medical information was available for most of the individuals limited the discussion. As strategies to recruit a higher number of donors, we identified the need to provide more detailed information on brain donations, to promote dialogue among families about tissue donation, and to give explanations on how research can contribute to the community and future generations. ${ }^{38}$

The results of this study suggested that deposits of a single type of anomalous protein are normal findings of an aging brain, while more than one kind or the combined presence of anomalous protein deposit indicate the presence of dementia, further measured by the IQCODE.

The systematic comparison of clinical dementia with pathological diagnosis allows essential feedback to improve the diagnostic process and further understanding on the pathophysiology of diseases. The importance of understanding neurodegenerative mechanisms, particularly premature changes in the EC - a vulnerable brain region in cases of dementia - justifies the effort and expense of research, especially in countries such as Brazil.

Author contribution. Edson Rodrigues Neto: development of project, brain collection and interviews with next-of-kin, laboratory analysis and writing the article. Mariana K Fonseca, Álvaro CB Guedes, Francine $\mathrm{H}$ Oliveira: brain collection and interviews with next-of-kin. Professors Arlete Hilbig and Liana Lisboa Fernandez: project supervision, laboratory analysis and writing the article.

Acknowledgments. This study was conducted with financial support from the Fundação de Amparo à Pesquisa do Rio Grande do Sul (FAPERGS). The authors acknowledge the support of the Forensics Department (FD) of Porto Alegre. 


\section{REFERENCES}

1. Brasil. Indicadores básicos para a saúde no Brasil: conceitos e aplicações. In: Saúde RIdlpa, editor. 2 ed. Brasília: Organização Pan-Americana da Saúde; 2008: 349.

2. Censo Demográfico 2010. Características da população e dos domicílios: resultados do universo. Rio de Janeiro: IBGE, 2011. Available on: <http://www.ibge.gov.br/home/estatistica/populacao/censo2010/ caracteristicas_da_populacao/resultados_do_universo.pdf $>$. Accessed on June 2015

3. Eftekharzadeh B, Hyman BT, Wegmann S. Structural studies on the mechanism of protein aggregation in age related neurodegenerative diseases. Mech Ageing Dev. 2016;156:1-13.

4. Aguzzi A, O'Connor T. Protein aggregation diseases: pathogenicity and therapeutic perspectives. Nat Rev Drug Discov. 2010;9(3):237-48.

5. Ferrer I. Defining Alzheimer as a common age-related neurodegenerative process not inevitably leading to dementia. Prog Neurobiol. 2012;97(1);38-51

6. Prado M, Caramelli P, Ferreira S, Cammarota M, Izquierdo I. Envelhecimento e memória: foco na doença de Alzheimer. Revista USP. 2007;75:42-9

7. Starr JM, Walesby KE. Diagnosis and management of dementia in older people. Medicine. 2016;41(1):43-46.

8. Nussbaum RL, Ellis CE. Alzheimer's disease and Parkinson's disease. N Engl J Med. 2003;348(14):1356-64.

9. Frota NAF, Nitrini R, Damasceno BP, Forlenza OV, Dias-To7sta E, Silva $A B$, et al. Criteria for the diagnosis of Alzheimer's disease: Recommendations of the Scientific Department of Cognitive Neurology and Aging of the Brazilian Academy of Neurology. Dement. Neuropsychol. 2011;5(3):146-52.

10. Ferrer I, Martinez A, Blanco R, Dalfó E, Carmona M. Neuropathology of sporadic Parkinson disease before the appearance of parkinsonism: preclinical Parkinson disease. J Neural Transm. 2011:118(5):821-39.

11. Braak H, Del Tredici K, Rüb U, Vos RA, Jansen Steur EN, Braak E. Staging of brain pathology related to sporadic Parkinson's disease. Neurobiol Aging. 2003;24(2):197-211.

12. Federoff M, Schottlaender LV, Houlden H, Singleton A. Multiple system atrophy: the application of genetics in understanding etiology. Clin Auton Res. 2015;25(1):19-36.

13. Lopez-Pousa S, Garre-Olmo J, Turon-Estrada A, Fajardo-Tibau C, Puig-Vidal O, Lozano-Gallego M, et al. Incidencia clínica de la dementia frontal. Rev Neurol. 2002;34(3):216-22.

14. Kwong LK, Uryu K, Trojanowski JQ, Lee VM. TDP-43 proteinopathies: neurodegenerative protein misfolding diseases without amyloidosis. Neuro-signals. 2008;16(1):41-51

15. van Eersel J, Bi M, Ke YD, Hodges JR, Xuereb JH, Gregory GC, et al Phosphorylation of soluble tau differs in Pick's disease and Alzheimer's disease brains. J Neural Transm. 2009;116:1243-51.

16. Leyton CE, Hodges JR. Frontotemporal dementias: Recent advances and current controversies. Ann Indian Acad Neurol. 2010 (suppl 2): S74-80.

17. Neumann M, Sampathu DM, Kwong LK, Truax AC, Micsenyi MC, Chou TT, et al. Ubiquitinated TDP-43 in Frontotemporal Lobar Degeneration and Amyotrophic Lateral Sclerosis. Science. 2006;314(5796):130-3.

18. Chrobak JJ, Lörincz A, Buzsáki G. Physiological Patterns in the Hippocampo-Entorhinal Cortex System. Hippocampus. 2000;10(4):457-65.

19. Thomas LD, Gonzales MF, Chamberlain A, Beyreuther K. Masters CL, Flicker L. Comparison of clinical state, retrospective informant interview and the neuropathologic diagnosis of Alzheimer's disease. Int J Geriatr Psychiatry. 1994:9(3):233-6.
20. Sanchez MAS, Lourenço RA. Informant Questionnaire on Cognitive Decline in the Elderly (IQCODE): adaptação transcultural para uso no Brasil. Cad Saúde Pública. 2009;25(7):1455-65.

21. Braak H, Braak E. Neuropathology staging of Alzheimer-related changes. Acta Neuropathol. 1991;82:239-59.

22. Mirra SS, Heyman A, McKeel D, Sumi SM, Crain BJ, Brownlee LM, et al. The Consortium to Establish a Registry for Alzheimer's Disease (CERAD). Part II. Standardization of the neuropathologic assessment of Alzheimer's disease. Neurology. 1991;41(4):479-86

23. Beardsall L, Barkley C, AO'Sullivan. The response of elderly community residents to request for brain donation: An interim report. Int J Geriatr Psychiatry. 1992;7(3):199-202.

24. Garrick T, Sundqvist N, Dobbins T, Azizi L, Harper C. Factors that influence decisions by families to donate brain tissue for medical research. Cell Tissue Bank. 2009;10(4):309-15

25. Schmitt FA, Wetherby MM, Wekstein DR, Dearth CM, Markesbery WR Brain donation in normal aging: procedures, motivations, and donor characteristics from the Biologically Resilient Adults in Neurological Studies (BRAiNS) Project. Gerontologist. 2011;41(6):716-22.

26. Grinberg LT, Nitrini R, Suemoto CK, Lucena Ferretti-Rebustini RE, Leite $\mathrm{RE}$, Farfel JM, et al. Prevalence of dementia subtypes in a developing country: a clinicopathological study. Clinics (Sao Paulo). 2013:68(8): 1140-5.

27. Farfel JM, Nitrini R, Suemoto CK, Grinberg LT, Ferretti RE, Leite RE, et al. Very low levels of education and cognitive reserve. Neurology. 2013;81(7):650-7.

28. Brunnstrom H, Englund E. Clinicopathological Concordance in Dementia Diagnosis. Am J Geriatr Psychiatry. 2009;7(8):664-70.

29. Serrano-Pozo A, Frosch MP, Masliah E, Hyman BT. Neuropathological Alterations in Alzheimer Disease. Cold Spring Harb Perspect Med. 2011:1(1):a006189

30. Niblock M, Hortobágyi T, Troakes C, Al-Sarraj S, Spickett C, Jones R, et al. Lack of association between TDP-43 pathology and tau mis-splicing in Alzheimer's Disease. Neurobiol Aging. 2016;37:45-6.

31. Nag S, Yu L, Capuano AW, Wilson RS, Leurgans SE, Bennett DA, Schneider JA. Hippocampal sclerosis and TDP-43 pathology in aging and Alzheimer Disease. Ann Neurol. 2015;77(6):942-52.

32. Farid K, Carter SF, Rodriguez-Vieitez E, Almkvist O, Andersen P, Wall A, et al. Case report of complex Amyotrophic Lateral Sclerosis with cognitive impairment and cortical amyloid deposition. J Alzheimers Dis. 2015;47(3):661-7.

33. Jellinger K. Neuropathology of Multiple Systems Atrophy: new thoughts about pathogenesis. Mov Dis. 2014;29(14):1720-41.

34. Cykowski MD, Coon EA, Powell SZ, Jenkins SM, Benarroch EE, Low PA et al. Expanding the spectrum of neuronal pathology in Multiple Systems Atrophy. Brain. 2015;138:2293-309.

35. Perl DP. Neuropathology of Alzheimer's Disease. Mt Sinai J Med. 2010; 77(1):32-42.

36. Selkoe D, Mandelkow E, Holtzman D. Deciphering Alzheimer Disease. Cold Spring Harb Perspect Med. 20122(1):a011460. Cold Spring Harb Perspect Med. 2012;2(1):a011460.

37. Fonseca MK, Rodrigues-Neto E, Costa AS, Rockembach MA, Padilha $R S$, Fernandez LL, et al. Assessing families' and patients' attitudes toward brain donation for research purposes in a Brazilian population sample. Cell Tissue Banking, 2014;16:287-94.

38. Lambe SCN. Perceptions, knowledge, incentives, and barriers of brain donation among African American elders enrolled in an Alzheimer's research program. Gerontologist. 2011;51(1):28-38. 